\title{
Inbreeding depression and performance of partially self-fertilized maize progenies in a top cross
}

\author{
Andreia Somera ${ }^{1}$, Angelita L.S.L. Ragagnin ${ }^{1}$, Maraiza L. Costa ${ }^{1}$, Willame dos S. Candido ${ }^{1}$, \\ and Edésio F. dos Reis ${ }^{1 *}$ \\ ${ }^{1}$ Universidade Federal de Goiás - Regional Jataí, BR 364 km 194 n 3800, 75800-000 Jataí, Goiás, Brasil. \\ *Corresponding author (edesiofr7@gmail.com).
}

Received: 14 March 2018; Accepted: 14 May 2018; doi:10.4067/S0718-58392018000300318

\begin{abstract}
Information on the effect of endogamy and combining ability of inbred families is essential in hybrid maize (Zea mays L.) breeding programs. The objective of this study was to evaluate the effect of inbreeding in a maize population and the performance of top-cross hybrids from this population, with a broad genetic base tester. First, $110 \mathrm{~S}_{1}$ families were generated and established in the field along with families from the original population. The experiment was arranged in a randomized block design with three replicates, in $3.0 \mathrm{~m}$ plots with 15 plants. Traits of agronomic importance, inbreeding depression, and the general effect of dominance deviations were estimated the first stage. In the second stage, 69 inbred families $\left(\mathrm{S}_{2}\right)$ with low inbreeding depression were evaluated by top-cross tests using the $\mathrm{F}_{2}$ generation of the commercial hybrid AG 6040 as tester. The same traits from the first stage were evaluated. Inbreeding depression in the first stage was higher for traits related to production, which indicates that the heterozygous loci contribute more to these traits, with the additive effects being less important. In the second stage, the best estimates of the general combining ability (GCA) for grain weight were found in progenies 51,33,17,9,3, and 67, showing good performance and good potential for use in breeding programs.
\end{abstract}

Key words: Hybrid, $S_{2}$ line, synthetic variety, Zea mays.

\section{INTRODUCTION}

In maize (Zea mays L.), as in other cross-pollinating crops, the presence of heterozygotes prevents deleterious genes from occurring in the homozygous state and reduce the manifestation of traits of interest to breeders. Thus, in these crops, according to Hallauer et al. (2010), it is essential to generate base populations that can be used in the future as a source of inbred lines to obtain superior hybrids. Vencovsky and Barriga (1992) recommend that selection of the best populations and collection of information on the lines should be based on genetic parameters related to the following factors: behavior of the lines when in total homozygosity, inbreeding depression, estimated additive effects $(m+a)$, and the contribution of heterozygous loci (d).

The higher the frequency of heterozygous loci in the genetic material, the greater the possibility of obtaining different gene combinations when total homozygosity is achieved. Inbreeding depression can be predicted if heterozygosity exists (Botelho et al., 2016). However, in the evaluation of genetic material, it is important to consider both the additive effect, which is estimated when all loci are homozygous, and the dominance effect, which is related to the level of inbreeding depression. Oliveira et al. (2015) studied three semiexotic populations of maize (CRE-1, CRE-2, and CRE-3). They found 
depression by inbreeding with one generation of self-fertilization, indicating that the phenotypic mean value of the three populations under inbreeding reduced in comparison with the random-mating population. Thus, depression by inbreeding can be defined as the reduction of the mean phenotypic value shown by traits associated with the reproductive capacity or physiological efficiency of the plant. Inbreeding depression may limit the number of promising lines in a germplasm and indicate the potential of populations for genetic breeding (Hallauer et al., 2010). The deleterious effects of inbreeding are direct consequences of the number and types of Mendelian traits found in heterozygosis in the original population, and are therefore a consequence of Mendelian segregation. In summary, germplasm sources that are more sensitive to inbreeding are the least promising for obtaining high potential agronomic lines, which may limit the achievement of promising hybrids (Hallauer, 1990).

The evaluation of inbreeding only may not be sufficient for guiding a selection program and advancing plant improvement. Thus, one should select lines using methodologies that allow their evaluation in different combinations. Among these methods, top crosses are used to evaluate the relative merit of a large number of partially inbred lines in crosses with testers and help the breeder to remove the lines with low performance (Miranda Filho and Viégas, 1987; Paterniani et al., 2006; Aguiar et al., 2008; Nelson and Goodman, 2008; Marcondes et al., 2015). The hybrid obtained from a top cross is very important for breeding programs. It is widely used to evaluate the combining ability of the progenies (or lines) and to select new lines at the initial stages of the program.

From the foregoing, therefore, the objectives of this study were to characterize self-fertilized lines $\left(\mathrm{S}_{1}\right)$ of maize for several attributes of agronomic importance, including sensitivity to inbreeding, evaluate the behavior of $S_{2}$ progenies in top crosses, and obtain experimental data on the productive and agronomic potential of the hybrid combinations.

\section{MATERIAL AND METHODS}

The experiment was divided into two stages: the first stage, comprising the evaluation of inbreeding depression, and the second stage, comprising the evaluation of the combining ability in top cross after advancement of a generation of selffertilization of the selected progenies in the first stage.

The original population derives from a promising material for fecundity. One cycle of recurrent selection was applied to this population for grain production. After recombination, a batch of approximately 500 seeds was sown to generate the inbred families ( $\mathrm{S}_{1}: 50 \%$ expected homozygosity). In this batch, 250 plants were self-fertilized in the reproductive stage, generating $110 \mathrm{~S}_{1}$ families with good-quality seeds in sufficient quantities for the test. The field trial was implemented in February 2015 (second harvest), with $\mathrm{S}_{1}$ progenies planted in a randomized block design, with three replicates. Each plot consisted of a $3 \mathrm{~m}$ long row, spaced $0.9 \mathrm{~m}$ between rows and $0.2 \mathrm{~m}$ between plants. Plants were thinned $25 \mathrm{~d}$ after planting to standardize the stand to 15 plants per plot. Lines of the base population were randomly introduced among the $S_{1}$ progenies. These lines originated from the random mating of the base population $\left(\mathrm{S}_{0}\right)$ that underwent self-fertilization to achieve inbreeding depression. To prevent the effect of competition between the lines of the base population $\left(\mathrm{S}_{0}\right)$ and the inbred lines, we planted two border rows around each row of the base population for protection, using the same population. In addition, we planted, on the outside of these two rows, a border row on each end, using a mixture of inbred lines.

The experiment was implanted in no-tillage system, with manual seeding in furrows. NPK was applied $\left(310 \mathrm{~kg} \mathrm{ha}^{-1} \mathrm{of}\right.$ the formula 04-20-18) according to fertilizer recommendation for the maize crop. Pests were controlled with application of insecticide and weeds with post-emergence herbicide.

Five plants from each plot were used to evaluate the following traits: male flowering (MF, d), when $50 \%$ of plants in the plot had a third of the tassel producing pollen; female flowering (FF, d), when 50\% of plants in the plot had at least $1 \mathrm{~cm}$ of style-stigma exposed; plant height (PH, $\mathrm{m})$, average of five random plants from the middle of the plot measured from ground to point of flag leaf insertion; ear insertion height (EH, m), average of five random plants from the middle of the plot measured from ground to the highest ear insertion; ear length (EL, cm), taken from five ears randomly sampled; ear diameter (ED, cm), taken from five ears randomly sampled. Ear weight without husks (EW) and grain weight adjusted to $13 \%$ moisture (GW) were determined for the entire plot. The ANOVA for the traits PH, EH, EL, and ED used plot means, and for EW and GW used the entire plot data transformed into $\mathrm{th}^{-1}$ and corrected to the ideal number of ears (15 ears) according to the covariance method (Vencovsky and Barriga, 1992). 
In the analysis of inbreeding depression, we used the inbred families $\left(\mathrm{S}_{1}\right)$ and plots that were representative of the base population (random pollination), from the same population, which allowed us to estimate the population parameters. We used the basic model adopted by Oliveira et al. (2015) for population mean, as follows:

$$
m_{0}=\mathrm{u}+a^{*}+d^{*}=A+d^{*}
$$

where $\mathrm{u}$ is half of the difference between the genotypic values of homozygotes for all loci; $a^{*}$ is the contribution of homozygotes to the mean; $d^{*}$ is the contribution of heterozygotes to the mean.

In a population at Hardy-Weinberg equilibrium, we can define: $a^{*}=\Sigma_{i}\left(2 p_{i}-1\right) a_{i}$ and $d^{*}=\Sigma_{i} 2 p_{i}\left(1-p_{i}\right) d_{i}$, where, at the $\mathrm{i}^{\text {th }}$ locus $p_{i}$ is the frequency of favorable alleles, $a_{i}$ is the effect of the homozygotes, and $d_{i}$ is the deviation of the heterozygotes.

After one generation of self-fertilization, the expected mean of the population with $50 \%$ of homozygosity is $m_{l}=\mathrm{u}+a^{*}+\frac{1}{2} d^{*}$, and the following effects are estimated:

$\hat{A}=2 m_{1}-m_{0}$ : expected mean of a random sample of completely homozygous lines extracted from the base population $E(\hat{A})=\mathrm{u}+a^{*}$.

$d^{*}=2\left(m_{0}-m_{1}\right):$ contribution of heterozygotes to the mean.

$d p=m_{1}-m_{0}$ : expected inbreeding depression when $50 \%$ of the population reach homozygosity.

In the second stage of the study, the assay with the $110 \mathrm{~S}_{1}$ families was conducted along with the estimation of the inbreeding depression. For this purpose, each family was sown in one 2-m row with at least 10 plants. All the plants were self-fertilized in the reproductive phase. After the estimation of inbreeding depression in the first stage, we selected the $\mathrm{S}_{2}$ families to be used in the field with a broad genetic base tester to determine the general combining ability (GCA) of the families. Among the original progenies, 36 were selected, in which 32 had lower inbreeding depression and 4 had greater inbreeding depression for grain production. Each $S_{1}$ line, which gave rise to the $S_{2}$ progenies, had approximately 10 plants, we then obtained 76 families after selection for seed quantity and sanity to generate the top cross hybrids. These progenies were crossed with a broad genetic based tester ( $F_{2}$ generation of commercial hybrid - AG 6040), using a crossing system in which one row of the tester was planted every three rows of the inbred lines. At the flowering time, the plants on the rows of inbred lines were emasculated and the tester ( $F_{2}$ of the hybrid AG6040) was used as the pollen donor. At harvest, seeds in sufficient quantities and with good sanity were obtained from 69 inbred lines, corresponding to the number of hybrids to be tested.

The experiment to evaluate of the top cross hybrids was installed in February 2016, in the second crop. It was arranged in a randomized complete block design, with four replicates. The plots consisted of one 4-m row spaced $0.9 \mathrm{~m}$ between rows and $0.2 \mathrm{~m}$ between plants. A total of 69 top cross hybrids were used. The commercial hybrid AG1051 was planted between rows as a control.

Sowing was carried manually in furrows, in no-tillage system. NPK was applied ( $310 \mathrm{~kg} \mathrm{ha}^{-1}$ of the formula 0420-18) according to fertilizer recommendation for the maize crop. The traits evaluated were the same as those in the first stage.

The estimation of the combining ability $\left(\mathrm{g}_{\mathrm{i}}\right)$ was performed with the statistical-genetic model described by Ferreira et al. (2009):

$$
Y_{i j}=m+g_{i}+e_{i j}
$$

where, $m$ is overall mean, $g_{i}$ is the effect of combining ability of line $\mathrm{i}$, and $e_{i j}$ is the mean experimental error. The parameter $\mathrm{g}_{\mathrm{i}}$ was obtained from the expression: $g_{i}=c_{i}-c$; where $\mathrm{g}_{\mathrm{i}}$ is the effect of combining ability of the lines, $c_{i}$ is the mean of each hybrid, and $c$ is the overall mean of the top cross hybrids.

All statistical and genetic analyses were performed using the GENES software (Cruz, 2013).

\section{RESULTS AND DISCUSSION}

The ANOVA of data from the first stage showed significant difference $(\alpha \leq 0.01)$ among the progenies for all evaluated variables, confirming the variability in the progenies (Table 1). The existence of genetic variability is essential for the success of plant breeding programs, since it allows the selection of superior genotypes.

Table 1 indicates that, among the traits evaluated, those related to production (EW and GW) had the highest inbreeding depression (ID), with means reaching $50.43 \%$ (EW) and 50.32\% (GW). Several studies reported ID higher for the 
Table 1. Mean square, observed means of the base population $\left(m_{0}\right)$ and $S_{1}\left(m_{1}\right)$, range of variation (YU: upper; YL: lower), inbreeding depression from $S_{0}$ to $S_{1}$ (ID), percentage of inbreeding depression (ID\%), homozygote (A) and heterozygote $\left(d^{*}\right)$ contribution to the mean observed in eight traits evaluated in a maize population obtained from the recombination of families selected from the synthetic variety TG-02 for fecundity.

\begin{tabular}{|c|c|c|c|c|c|c|c|c|c|}
\hline & \multicolumn{9}{|c|}{ Trait } \\
\hline & Mean & MF & $\mathrm{FF}$ & $\mathrm{PH}$ & $\mathrm{EH}$ & ED & EL & EW & GW \\
\hline \multirow{4}{*}{$\begin{array}{c}\text { Progeny } \\
\text { Pop. B } \\
{[\mathrm{n}=18]}\end{array}$} & & $7.765 * *$ & $9.361 * *$ & $0.093 * *$ & $0.039 * *$ & $0.174 * *$ & $3.914 * *$ & $4316.415^{* *}$ & $2794.547 * *$ \\
\hline & $\mathrm{m}_{0}$ & 60.944 & 61.278 & 2.057 & 1.215 & 4.689 & 16.544 & 9070.773 & 7099.842 \\
\hline & YS & 62.000 & 63.000 & 2.240 & 1.376 & 5.000 & 18.600 & 11718.507 & 9203.694 \\
\hline & YI & 60.000 & 60.000 & 1.954 & 1.088 & 4.400 & 15.000 & 6881.474 & 5088.884 \\
\hline \multirow{7}{*}{$\begin{array}{c}\mathrm{S}_{1} \\
{[\mathrm{n}=110]}\end{array}$} & $\mathrm{m}_{1}$ & 62.818 & 62.936 & 1.777 & 1.044 & 4.074 & 13.925 & 4495.987 & 3527.224 \\
\hline & YS & 69.000 & 69.000 & 4.480 & 1.550 & 4.800 & 18.000 & 9296.290 & 7411.530 \\
\hline & YI & 58.000 & 58.000 & 1.264 & 0.650 & 3.000 & 10.600 & 336.300 & 681.760 \\
\hline & ID & -1.874 & -1.659 & 0.279 & 0.172 & 0.615 & 2.620 & 4574.786 & 3372.617 \\
\hline & ID $\%$ & -3.075 & -2.707 & 13.586 & 14.118 & 13.115 & 15.834 & 50.431 & 50.320 \\
\hline & $\mathrm{A}$ & 64.692 & 64.595 & 1.498 & 0.872 & 3.459 & 11.305 & -78.800 & -45.393 \\
\hline & $\mathrm{d}^{*}$ & -3.747 & -3.317 & 0.559 & 0.343 & 1.230 & 5.239 & 9149.973 & 7145.235 \\
\hline
\end{tabular}

MF: Male flowering (d), FF: female flowering (d), PH: plant height (m), EH: ear height (m), ED: mean ear diameter (cm), EL: mean ear length (cm), EW: ear weight (without husk, $\mathrm{kg} \mathrm{ha}^{-1}$ ), GW: grain weight (corrected to $13 \%$ moisture in $\mathrm{kg} \mathrm{ha}^{-1}$ ).

production variable than PH and EH (Scapim et al., 2006; Garbuglio et al., 2009; Bernini et al., 2013; Kuki et al., 2017). Good and Hallauer (1977) observed that production is the most affected variable by inbreeding in any degree of homozygosity. According to Kuki et al. (2017) and Bernini et al. (2013), inbreeding depression for PH and EH is lower than for EW and GW, because the dominance effects are less important in these traits.

There was increase in the number of days for both male and female flowering, indicating a negative effect of endogamy on $\mathrm{S}_{1}$ generation. The percentages of inbreeding depression found were -3.075 and $-2.707 \%$ for male and female flowering, respectively.

Plant height (PH) and ear insertion height (EH) showed inbreeding depression of $13.57 \%$ and $14.12 \%$, respectively, with decrease in $\mathrm{PH}$ and $\mathrm{EH}$, which indicates a depressive effect due to endogamy. Similar results of inbreeding depression for these two characters were found by Arnhold et al. (2010) in a popcorn population. We also recorded decrease in mean values of ear length (EL) and ear diameter (ED), with inbreeding depression percentages of $15.83 \%$ and $13.12 \%$, respectively. These results corroborate with the findings of Garbuglio et al. (2009), with percentages of inbreeding depression below 15\% for EL and ED. Thus, indicating that for these traits, the dominance effects are also less severe, resulting in less inbreeding depression.

In a comprehensive review on maize breeding techniques, Hallauer (1990) found that when comparing inbred with non-inbred lines, $\mathrm{PH}$ can be reduced by $25 \%$, number of days for flowering can increase by $6.8 \%$, and grain yield can be reduced by up to $68 \%$, on average.

Inbreeding depression was more pronounced in ear weight (EW) and grain weight (GW), with mean percentages of $50.43 \%$ and $50.32 \%$, respectively. These high values are expected because of the complexity of these traits. Arnhold et al. (2010) and Freitas et al. (2016) argue that for quantitative inheritance traits, the contribution of heterozygous loci is high and influences the increase of inbreeding depression. Bernini et al. (2013) found inbreeding depression rates for the trait GW in hybrids of $48.1 \%, 39.2 \%$, and $36.3 \%$, corroborating with the results found in the present study. Table 1 shows stronger dominance effects for the two traits.

As Table 2 indicates, there is a variation in the percentage of inbreeding depression from $2.60 \%$ to $79.45 \%$ for the 110 progenies evaluated. Progeny 79 had the lowest inbreeding depression (2.60\%) and progeny 109 had the greatest inbreeding depression $(79.45 \%)$. Other progenies with low inbreeding depression were $8,69,52,10$, and 79 , with percentages of $33.12 \%, 27.21 \%, 23.82 \%, 17.90 \%$, and $2.60 \%$, respectively. These progenies are less sensitive to the effect of inbreeding and can generate lines with greater yield potential, because of the high frequency of favorable alleles.

By comparing the contribution of homozygote (A) and heterozygote $\left(\mathrm{d}^{*}\right)$ (Table 1), one sees that the traits $\mathrm{PH}$ and EH have a higher contribution of homozygous loci (additive effects) and lower contribution of heterozygous loci 
Table 2. Estimates of inbreeding depression (ID), percentage of inbreeding depression (ID\%), homozygote (A) and heterozygote $\left(d^{*}\right)$ contribution from means of grain production per $3 \mathbf{~ m}$ plot, for each progeny.

\begin{tabular}{|c|c|c|c|c|c|c|c|c|c|}
\hline Progeny & ID & ID \% & A & $\mathrm{d}^{*}$ & Progeny & ID & ID \% & A & $d^{*}$ \\
\hline 1 & 0.658 & 34.34 & 0.600 & 1.317 & 56 & 1.085 & 56.59 & -0.253 & 2.170 \\
\hline 2 & 0.868 & 45.30 & 0.180 & 1.737 & 57 & 1.270 & 66.26 & -0.623 & 2.540 \\
\hline 3 & 0.676 & 35.28 & 0.564 & 1.352 & 58 & 1.171 & 61.10 & -0.425 & 2.342 \\
\hline 4 & 1.195 & 62.32 & -0.472 & 2.389 & 59 & 0.690 & 35.98 & 0.538 & 1.379 \\
\hline 5 & 0.721 & 37.60 & 0.476 & 1.441 & 60 & 0.995 & 51.89 & -0.073 & 1.990 \\
\hline 6 & 0.641 & 33.41 & 0.636 & 1.281 & 61 & 0.864 & 45.09 & 0.188 & 1.729 \\
\hline 7 & 0.783 & 40.85 & 0.351 & 1.566 & 62 & 0.882 & 46.01 & 0.153 & 1.764 \\
\hline 8 & 0.635 & 33.12 & 0.647 & 1.270 & 63 & 1.307 & 68.18 & -0.697 & 2.614 \\
\hline 9 & 0.952 & 49.66 & 0.013 & 1.904 & 64 & 1.083 & 56.49 & -0.249 & 2.166 \\
\hline 10 & 0.343 & 17.90 & 1.231 & 0.686 & 65 & 1.097 & 57.24 & -0.278 & 2.194 \\
\hline 11 & 1.358 & 70.84 & -0.799 & 2.716 & 66 & 0.682 & 35.59 & 0.552 & 1.365 \\
\hline 12 & 0.741 & 38.66 & 0.435 & 1.482 & 67 & 1.288 & 67.22 & -0.660 & 2.577 \\
\hline 13 & 0.887 & 46.29 & 0.142 & 1.775 & 68 & 0.896 & 46.72 & 0.126 & 1.791 \\
\hline 14 & 0.749 & 39.06 & 0.419 & 1.498 & 69 & 0.522 & 27.21 & 0.874 & 1.043 \\
\hline 15 & 0.739 & 38.55 & 0.439 & 1.478 & 70 & 1.322 & 68.94 & -0.726 & 2.643 \\
\hline 16 & 1.080 & 56.36 & -0.244 & 2.161 & 71 & 1.031 & 53.78 & -0.145 & 2.062 \\
\hline 17 & 1.050 & 54.78 & -0.183 & 2.100 & 72 & 1.285 & 67.05 & -0.654 & 2.571 \\
\hline 18 & 0.785 & 40.94 & 0.347 & 1.570 & 73 & 1.058 & 55.20 & -0.200 & 2.116 \\
\hline 19 & 1.147 & 59.83 & -0.377 & 2.294 & 74 & 0.711 & 37.10 & 0.494 & 1.422 \\
\hline 20 & 1.077 & 56.16 & -0.236 & 2.153 & 75 & 0.772 & 40.29 & 0.372 & 1.545 \\
\hline 21 & 1.072 & 55.92 & -0.227 & 2.144 & 76 & 0.814 & 42.46 & 0.289 & 1.628 \\
\hline 22 & 1.089 & 56.83 & -0.262 & 2.179 & 77 & 1.000 & 52.17 & -0.083 & 2.000 \\
\hline 23 & 0.834 & 43.48 & 0.250 & 1.667 & 78 & 1.083 & 56.51 & -0.250 & 2.167 \\
\hline 24 & 0.645 & 33.62 & 0.628 & 1.289 & 79 & 0.050 & 2.60 & 1.817 & 0.100 \\
\hline 25 & 0.933 & 48.67 & 0.051 & 1.866 & 80 & 1.146 & 59.78 & -0.375 & 2.292 \\
\hline 26 & 1.166 & 60.83 & -0.415 & 2.332 & 81 & 1.176 & 61.33 & -0.434 & 2.351 \\
\hline 27 & 0.674 & 35.15 & 0.569 & 1.348 & 82 & 1.276 & 66.56 & -0.635 & 2.552 \\
\hline 28 & 0.756 & 39.44 & 0.405 & 1.512 & 83 & 0.905 & 47.19 & 0.108 & 1.809 \\
\hline 29 & 0.728 & 37.97 & 0.461 & 1.456 & 84 & 1.331 & 69.42 & -0.745 & 2.662 \\
\hline 30 & 0.727 & 37.92 & 0.463 & 1.454 & 85 & 1.437 & 74.97 & -0.957 & 2.874 \\
\hline 31 & 0.643 & 33.54 & 0.631 & 1.286 & 86 & 0.754 & 39.31 & 0.410 & 1.507 \\
\hline 32 & 1.172 & 61.16 & -0.428 & 2.345 & 87 & 0.947 & 49.42 & 0.022 & 1.895 \\
\hline 33 & 1.055 & 55.03 & -0.193 & 2.110 & 88 & 0.830 & 43.31 & 0.256 & 1.660 \\
\hline 34 & 0.823 & 42.92 & 0.271 & 1.646 & 89 & 1.185 & 61.81 & -0.453 & 2.370 \\
\hline 35 & 0.994 & 51.87 & -0.072 & 1.989 & 90 & 1.084 & 56.52 & -0.250 & 2.167 \\
\hline 36 & 0.364 & 19.01 & 1.188 & 0.729 & 91 & 1.358 & 70.83 & -0.799 & 2.716 \\
\hline 37 & 0.845 & 44.08 & 0.227 & 1.690 & 92 & 1.018 & 53.10 & -0.119 & 2.036 \\
\hline 38 & 1.020 & 53.23 & -0.124 & 2.041 & 93 & 1.173 & 61.17 & -0.428 & 2.345 \\
\hline 39 & 0.841 & 43.88 & 0.235 & 1.682 & 94 & 0.947 & 49.38 & 0.024 & 1.893 \\
\hline 40 & 1.040 & 54.25 & -0.163 & 2.080 & 95 & 1.223 & 63.79 & -0.529 & 2.446 \\
\hline 41 & 1.080 & 56.33 & -0.243 & 2.160 & 96 & 0.992 & 51.75 & -0.067 & 1.984 \\
\hline 42 & 0.841 & 43.85 & 0.236 & 1.681 & 97 & 1.475 & 76.95 & -1.033 & 2.950 \\
\hline 43 & 0.822 & 42.90 & 0.272 & 1.645 & 98 & 1.305 & 68.07 & -0.693 & 2.610 \\
\hline 44 & 0.696 & 36.33 & 0.524 & 1.393 & 99 & 0.906 & 47.26 & 0.105 & 1.812 \\
\hline 45 & 0.960 & 50.07 & -0.003 & 1.920 & 100 & 0.785 & 40.96 & 0.347 & 1.570 \\
\hline 46 & 1.156 & 60.32 & -0.396 & 2.313 & 101 & 1.425 & 74.32 & -0.932 & 2.849 \\
\hline 47 & 0.896 & 46.73 & 0.126 & 1.791 & 102 & 1.022 & 53.33 & -0.128 & 2.045 \\
\hline 48 & 0.883 & 46.07 & 0.151 & 1.766 & 103 & 0.810 & 42.24 & 0.297 & 1.619 \\
\hline 49 & 1.111 & 57.95 & -0.305 & 2.222 & 104 & 0.893 & 46.57 & 0.131 & 1.786 \\
\hline 50 & 0.842 & 43.92 & 0.233 & 1.684 & 105 & 0.655 & 34.17 & 0.607 & 1.310 \\
\hline 51 & 1.213 & 63.28 & -0.509 & 2.426 & 106 & 1.220 & 63.63 & -0.523 & 2.440 \\
\hline 52 & 0.457 & 23.82 & 1.004 & 0.913 & 107 & 0.777 & 40.54 & 0.363 & 1.554 \\
\hline 53 & 1.038 & 54.13 & -0.158 & 2.075 & 108 & 1.294 & 67.48 & -0.670 & 2.587 \\
\hline 54 & 1.146 & 59.76 & -0.374 & 2.291 & 109 & 1.523 & 79.45 & -1.129 & 3.046 \\
\hline 55 & 1.474 & 76.88 & -1.031 & 2.948 & 110 & 1.159 & 60.45 & -0.400 & 2.317 \\
\hline
\end{tabular}


(dominance deviations), whereas the traits EW and GW have a higher contribution of heterozygous loci and less of homozygous loci. This shows that for the traits related to production, the contribution of heterozygous loci is more pronounced, and additive effects are less important than dominance deviations. These findings are consistent with those of Viana et al. (2009), who used mean estimates of lines obtained from simple maize hybrids and estimated the contribution of homozygous loci for PH, EH, EW, and GW to be 59.65\%, 53.16\%, 31.65\%, and $30.40 \%$, respectively. The contribution of heterozygous loci was estimated as $40.53 \%, 47.43 \%, 68.36 \%$, and $69.36 \%$, for the traits $\mathrm{PH}, \mathrm{EH}, \mathrm{EW}$, and GW, respectively. These results indicate a greater contribution of homozygous loci for the traits $\mathrm{PH}$ and $\mathrm{EH}$, and of heterozygous loci for the traits EW and GW, which is in good agreement with the results of the present study.

The progenies that presented the highest inbreeding depression were 109,97,55, 85, and 101 (Table 2), with percentages of $79.45 \%, 76.95 \%, 76.88 \%, 74.97 \%, 74.00 \%$, and $32.00 \%$, respectively. These five progenies are less promising for obtaining high standard agronomic lines because of their greater sensitivity to inbreeding effects, which may limit the development of promising hybrids.

We found that the contribution of heterozygous loci is higher in progenies that are more sensitive to the effect of inbreeding, because, in case of dominance controlling the target trait and heterozygous loci, inbreeding depression (ID) is likely to occur in the population. From the foregoing, we may infer that the estimate of inbreeding depression may indicate the contribution of the heterozygous loci (d) in the population (Lima et al., 2000).

Table 3 shows the estimates of general combining ability $\left(\hat{\mathrm{g}}_{\mathrm{i}}\right)$ effects for nine traits evaluated in 69 maize top cross hybrids. The effects of the general combining ability were estimated considering that the lines were crossed with a broad genetic based tester (population $\mathrm{F}_{2}$ ). These effects were estimated by the hybrid mean deviations in relation to the mean of all the top cross hybrids evaluated, according to methodology described by Ferreira et al. (2009).

The negative values of $\hat{\mathrm{g}}_{\mathrm{i}}$ for the flowering traits favor precocity. This result is of great interest, as it reduces the time of permanence of the crop in the field and thus reduces risks and production costs. The genotypes 58, 44, 64, 28, 2, and 27 , $51,44,6$, and 2 expressed a favorable reduction in the number of days for male and female flowering, since they showed the lowest $\hat{g}_{\mathrm{i}}$ values contributing to precocity.

Breeding to manipulate the traits $\mathrm{PH}$ and $\mathrm{EH}$ aims at reducing plant size to reduce stem lodging and breaking. Genotypes 4, 49, 53, and 54 had negative values of $\hat{\mathrm{g}}_{\mathrm{i}}$ for PH and genotypes 4, 49, 54, and 53, for $\mathrm{EH}$. The effects of $\hat{\mathrm{g}}_{\mathrm{i}}$ for PH and $\mathrm{EH}$ indicate that genotypes with negative values tend to accumulate genes favoring the reduction in size. Therefore, they are likely to contribute to reducing the size of plants. Fidelis et al. (2010) reported similar results evaluating the combining ability of tropical maize populations. They found that the presence of populations with negative GCA indicates the possibility of genetic gains for reduction of $\mathrm{PH}$ and EH. Ji et al. (2006) argue that $\mathrm{EH}$ is one of the most important traits in Z. mays selection programs, since it is directly related to lodging.

The $\hat{\mathrm{g}}_{\mathrm{i}}$ effects of the trait EL in the lines 27,33, 51, 67, and 21 exceeded the others. The trait ED in the lines 66, 12, 13, 14 , and 51 showed values superior to the others. Therefore, these lines have greater concentration of favorable alleles for the increase of these traits.

The genotypes 51, 9, 33, 32, and 67 stood out for presenting positive values of $\hat{\mathrm{g}}_{\mathrm{i}}$ for WE and genotypes 51, 33, 17, 9,3 , and 67 for GW. Genotype 51 was superior to all others ( $\hat{\mathrm{g}}_{\mathrm{i}}=2.146 \mathrm{t} \mathrm{ha}^{-1}$ for $\left.\mathrm{EW}\right)$ and $\left(\hat{\mathrm{g}}_{\mathrm{i}}=1.429 \mathrm{t} \mathrm{ha}{ }^{-1}\right.$ for GW). These results demonstrate that the use of these lines in crosses can increase yield. On the other hand, genotypes 1, 62, 43, 56 , and 40 indicate a lower possibility of yield increase. These genotypes express higher negative values of $\hat{\mathrm{g}}_{\mathrm{i}}$ for GW, showing little influence of the additive effect. Genotype 1 showed the greatest reduction $\left(\hat{\mathrm{g}}_{\mathrm{i}}=-1.165 \mathrm{tha}^{-1}\right)$. According to Senhorinho et al. (2015), positive values of $\hat{\mathrm{g}}_{\mathrm{i}}$ indicate that genotypes used as parents contributed with favorable alleles with additive effects to their progenies.

The top cross hybrids $66,67,68$, and 69 (Table 3 ) were selected from progenies $\left(S_{1}\right)$ with higher inbreeding depression for grain production. According to the literature, these progenies are less promising to obtain hybrids of high agronomic standard. The hybrids 66,67 , and 68 showed positive GCA estimates for GW, indicating good genetic complementarity with the tester, and negative GCA estimates for MF, FF and EH/PH ratio. They showed satisfactory productivity, cycle reduction, and size reduction, which is of interest, indicating that self-fertilization can be continued. Hybrid 69 had negative GCA estimate for GW, indicating low productivity. 
Table 3. Estimates of the effects of the general combining ability $\left(\hat{\mathrm{g}}_{\mathrm{i}}\right)$ for the nine traits evaluated in 69 maize top cross hybrids in an experiment conducted in Jataí, Goiás, in the harvest 2015-2016.

\begin{tabular}{|c|c|c|c|c|c|c|c|c|c|}
\hline \multirow[b]{2}{*}{ Hybrid } & \multicolumn{9}{|c|}{ Trait } \\
\hline & MF & FF & $\mathrm{PH}$ & EH & $\mathrm{EH} / \mathrm{PH}$ & EL & ED & EW & GW \\
\hline 1 & 0.971 & 4.467 & -0.002 & -0.015 & -0.009 & -1.876 & -0.104 & -1.179 & -1.165 \\
\hline 2 & -2.029 & -2.283 & 0.003 & -0.028 & -0.019 & 0.524 & -0.104 & 0.126 & 0.221 \\
\hline 3 & -0.279 & 0.467 & -0.037 & -0.020 & -0.001 & -0.276 & -0.404 & 0.563 & 0.433 \\
\hline 4 & 0.221 & -0.033 & -0.301 & -0.186 & -0.006 & -1.626 & -0.554 & -0.072 & 0.017 \\
\hline 5 & -1.529 & -1.783 & 0.124 & 0.034 & -0.024 & -0.426 & -0.004 & 0.206 & 0.243 \\
\hline 6 & -1.029 & -2.283 & 0.065 & 0.012 & -0.017 & -0.326 & 0.146 & 0.302 & 0.223 \\
\hline 7 & 1.721 & 0.717 & 0.002 & 0.011 & 0.006 & -0.076 & -0.104 & -0.011 & 0.128 \\
\hline 8 & -0.529 & -0.283 & 0.097 & 0.066 & 0.004 & -1.676 & 0.046 & -0.064 & -0.120 \\
\hline 9 & 2.721 & 0.467 & 0.039 & 0.060 & 0.024 & 0.824 & 0.246 & 1.184 & 0.606 \\
\hline 10 & 0.471 & 0.717 & 0.092 & 0.063 & 0.006 & 0.624 & 0.046 & 0.074 & 0.076 \\
\hline 11 & 0.221 & 0.217 & 0.001 & -0.035 & -0.023 & 0.974 & -0.004 & 0.219 & 0.213 \\
\hline 12 & 0.221 & 0.967 & 0.052 & 0.004 & -0.015 & 0.824 & 0.396 & 0.500 & 0.323 \\
\hline 13 & -1.529 & -1.533 & 0.030 & 0.025 & 0.005 & 0.974 & 0.296 & 0.245 & 0.135 \\
\hline 14 & -0.279 & 0.467 & 0.073 & 0.036 & -0.005 & -1.076 & 0.246 & 0.222 & 0.114 \\
\hline 15 & 2.471 & 3.967 & -0.026 & -0.021 & -0.003 & -0.626 & -0.104 & -0.037 & -0.029 \\
\hline 16 & 2.221 & 0.717 & -0.002 & 0.038 & 0.026 & -0.576 & 0.046 & -0.218 & -0.013 \\
\hline 17 & 0.971 & -1.283 & 0.021 & 0.058 & 0.030 & 0.674 & 0.196 & 0.580 & 0.638 \\
\hline 18 & 1.971 & 2.467 & 0.016 & 0.029 & 0.013 & -0.426 & -0.004 & 0.077 & 0.147 \\
\hline 19 & 1.721 & 0.217 & -0.064 & -0.047 & -0.006 & -1.076 & 0.096 & -0.143 & 0.049 \\
\hline 20 & -0.029 & 0.967 & -0.042 & -0.010 & 0.010 & 1.274 & 0.096 & 0.300 & -0.006 \\
\hline 21 & 0.471 & -0.283 & 0.044 & 0.070 & 0.028 & 0.924 & -0.054 & -0.311 & -0.294 \\
\hline 22 & -0.029 & -0.033 & 0.070 & 0.129 & 0.055 & 1.524 & -0.054 & -0.140 & 0.077 \\
\hline 23 & 0.971 & 0.717 & -0.012 & 0.037 & 0.031 & 1.124 & -0.254 & 0.482 & -0.222 \\
\hline 24 & -0.779 & -1.783 & 0.025 & 0.015 & 0.001 & -0.126 & -0.104 & 0.026 & 0.069 \\
\hline 25 & 0.471 & 2.217 & -0.028 & 0.000 & 0.012 & -0.826 & -0.354 & -0.364 & -0.347 \\
\hline 26 & -1.279 & -2.283 & 0.038 & 0.038 & 0.009 & 0.024 & -0.254 & -0.561 & -0.318 \\
\hline 27 & -1.529 & -3.533 & 0.084 & 0.110 & 0.039 & 2.724 & -0.104 & 0.394 & 0.382 \\
\hline 28 & -2.279 & -1.783 & 0.155 & 0.159 & 0.040 & 0.924 & -0.004 & 0.475 & 0.345 \\
\hline 29 & -0.529 & -0.783 & 0.107 & 0.113 & 0.029 & -0.076 & -0.154 & 0.057 & -0.034 \\
\hline 30 & 0.221 & -1.033 & 0.131 & 0.074 & -0.003 & 0.924 & 0.096 & -0.124 & 0.108 \\
\hline 31 & -0.529 & 0.467 & 0.097 & 0.013 & -0.027 & -0.726 & -0.404 & -0.381 & -0.146 \\
\hline 32 & 1.471 & 1.217 & 0.004 & -0.032 & -0.022 & 0.124 & 0.096 & 0.703 & 0.265 \\
\hline 33 & -1.529 & -0.533 & 0.003 & -0.013 & -0.007 & 1.924 & -0.104 & 0.881 & 0.709 \\
\hline 34 & -0.029 & -1.783 & 0.082 & 0.101 & 0.033 & -0.026 & -0.004 & -0.244 & -0.047 \\
\hline 35 & 1.471 & 1.467 & -0.063 & -0.028 & 0.006 & -0.376 & -0.004 & 0.243 & 0.111 \\
\hline 36 & -0.529 & -0.533 & 0.088 & 0.065 & 0.009 & -0.276 & -0.154 & -0.053 & -0.234 \\
\hline 37 & -0.029 & 0.217 & -0.046 & 0.006 & 0.024 & -1.176 & -0.254 & -0.778 & -0.391 \\
\hline 38 & 0.721 & 1.217 & -0.014 & -0.003 & 0.003 & 0.274 & 0.196 & 0.206 & 0.016 \\
\hline 39 & -2.029 & -1.783 & 0.008 & -0.004 & -0.006 & 0.274 & 0.196 & 0.200 & 0.340 \\
\hline 40 & -1.779 & -0.783 & 0.006 & 0.043 & 0.025 & -0.676 & 0.146 & -0.734 & -0.490 \\
\hline 41 & 0.721 & 2.467 & -0.097 & -0.056 & 0.002 & -0.176 & 0.146 & -0.341 & -0.476 \\
\hline 42 & 1.471 & -0.033 & -0.027 & 0.037 & 0.035 & 1.374 & 0.046 & 0.468 & 0.406 \\
\hline 43 & -1.529 & 0.467 & 0.009 & 0.098 & 0.060 & 0.524 & -0.054 & -0.475 & -0.530 \\
\hline 44 & -2.529 & -2.533 & -0.077 & -0.095 & -0.032 & 0.624 & 0.096 & 0.185 & 0.148 \\
\hline 45 & 0.471 & 0.467 & -0.052 & -0.092 & -0.042 & -0.526 & 0.046 & -0.415 & -0.175 \\
\hline 46 & -1.029 & -0.533 & -0.044 & 0.009 & 0.025 & -0.176 & 0.096 & -0.509 & -0.420 \\
\hline 47 & 0.721 & -0.283 & -0.027 & -0.025 & -0.007 & -0.326 & 0.196 & 0.345 & 0.237 \\
\hline 48 & 1.721 & 0.717 & 0.061 & -0.044 & -0.050 & -0.176 & 0.096 & -0.120 & -0.215 \\
\hline 49 & 2.221 & 3.217 & -0.262 & -0.175 & -0.023 & -1.626 & -0.204 & -0.382 & -0.237 \\
\hline 50 & -0.029 & 1.967 & -0.047 & -0.063 & -0.022 & -1.826 & -0.154 & -0.546 & -0.243 \\
\hline 51 & -1.279 & -2.533 & 0.137 & 0.044 & -0.023 & 1.674 & 0.246 & 2.146 & 1.429 \\
\hline 52 & 1.721 & 0.467 & -0.035 & -0.039 & -0.012 & 1.174 & -0.004 & -0.384 & 0.080 \\
\hline 53 & 0.471 & -1.533 & -0.151 & -0.108 & -0.013 & 0.824 & 0.046 & 0.243 & 0.239 \\
\hline 54 & 0.471 & 0.467 & -0.126 & -0.118 & -0.031 & -0.376 & 0.046 & -0.143 & -0.202 \\
\hline 55 & -1.529 & -0.533 & -0.127 & -0.053 & 0.015 & -0.326 & 0.196 & 0.434 & 0.279 \\
\hline 56 & 1.221 & -1.783 & 0.039 & 0.040 & 0.010 & -1.326 & -0.154 & -0.649 & -0.522 \\
\hline 57 & 0.471 & 0.217 & -0.045 & -0.035 & -0.005 & -0.726 & 0.046 & -0.251 & -0.169 \\
\hline 58 & -2.779 & -1.783 & -0.008 & -0.014 & -0.006 & 0.674 & -0.254 & -0.496 & -0.343 \\
\hline 59 & -0.279 & -0.783 & -0.002 & 0.027 & 0.019 & -0.276 & -0.054 & -0.012 & 0.019 \\
\hline 60 & 0.221 & -0.033 & 0.007 & 0.021 & 0.010 & 0.374 & -0.104 & -0.508 & -0.272 \\
\hline 61 & 1.221 & 4.217 & -0.040 & -0.104 & -0.053 & -1.476 & 0.046 & -0.518 & -0.382 \\
\hline 62 & 0.971 & -0.033 & -0.089 & -0.064 & -0.007 & -1.476 & -0.204 & -1.229 & -0.957 \\
\hline 63 & 1.221 & 1.217 & 0.094 & 0.084 & 0.017 & -0.626 & 0.196 & 0.351 & 0.152 \\
\hline 64 & -2.279 & -0.283 & 0.046 & -0.024 & -0.033 & -0.226 & -0.004 & -0.158 & -0.079 \\
\hline 65 & -1.779 & 1.467 & -0.020 & -0.024 & -0.008 & -0.926 & -0.204 & -0.744 & -0.453 \\
\hline 66 & 1.471 & 1.967 & 0.014 & -0.059 & -0.044 & 0.874 & 0.496 & 0.392 & 0.161 \\
\hline 67 & -0.529 & -2.033 & -0.069 & -0.061 & -0.015 & 1.574 & 0.196 & 0.677 & 0.418 \\
\hline 68 & -2.029 & -0.783 & -0.013 & -0.064 & -0.037 & -0.076 & 0.096 & -0.073 & 0.182 \\
\hline 69 & -0.779 & -1.783 & 0.025 & -0.009 & -0.014 & -0.126 & 0.096 & -0.144 & -0.201 \\
\hline
\end{tabular}

MF: Male flowering (d), FF: female flowering (d), PH: plant height (m), EH: ear height (m), EH/PH: ear height and plant height ratio, ED: mean

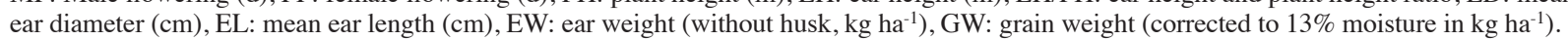




\section{CONCLUSIONS}

The highest values of inbreeding depression were found for productivity. Flowering showed low values of inbreeding depression, characterizing an increase in cycle.

The progenies $8,10,52,69$, and 79 were the least sensitive to the effect of inbreeding, showing low percentages of inbreeding depression and, therefore, being more promising for obtaining lines of high agronomic standard.

The top cross hybrids 51 and 33 stood out with the highest combining ability estimate for yield; the hybrids 4 and 49 for size reduction and ear insertion height; the hybrid 58 for precocity in male flowering; and the hybrid 27 for precocity in female flowering. The greatest contribution to the increase in ear diameter is found in hybrid 66 and increase in ear length in hybrids 27 and 33.

\section{REFERENCES}

Aguiar, C.G., Schuster, I., Amaral Júnior, A.T., Scapim, C.A., and Vieira, E.S.N. 2008. Heterotic groups in tropical maize germplasm by test crosses and simple sequence repeat markers. Genetics and Molecular Research 7:1233-1244. doi:10.4238/vol7-4gmr495.

Arnhold, E., Viana, J.M.S., Mora, F., Miranda, G.V., and Silva, R.G. 2010. Inbreeding depression and genetic components for popping expansion and other traits in Brazilian populations of popcorn. Ciencia e Investigación Agraria 37:125-132. doi:10.7764/rcia.v37i3.155.

Bernini, C.S., Paterniani, M.E.A.G.Z., Duarte, A.P., Gallo, P.B., Guimarães, P.S., e Rovaris, S.R.S. 2013. Depressão endogâmica e heterose de híbridos de populações $F_{2}$ de milho no estado de São Paulo. Bragantia 72:217-223. doi:10.1590/brag.2013.038.

Botelho, F.B.S., Bruzi, A.T., Lima, I.P., Rodrigues, C.S., and Botelho, R.T.C. 2016. Inbreeding depression in single, three way and double-cross hybrids of maize. Genetics and Molecular Research 15:1-7. doi:10.4238/gmr.15035497.

Cruz, C.D. 2013. GENES - a software package for analysis in experimental statistics and quantitative genetics. Acta Scientiarum Agronomy 35:271-276. doi:10.4025/actasciagron.v35i3.21251.

Ferreira, E.A., Paterniani, M.E.A.G.Z., Duarte, A.P., Gallo, P.B., Sawazaki, E., Azevedo Filho, J.A., et al. 2009. Desempenho de híbridos top crosses de linhagens $\mathrm{S}_{3}$ de milho em três locais do Estado de São Paulo. Bragantia 68:319-327. doi:10.1590/S0006-87052009000200005.

Fidelis, R.R., Miranda, G.V., e Faluba, J.S. 2010. Capacidade de combinação de populações de milho tropicais sob estresse de baixo nitrogênio. Bioscience Journal 26:358-366.

Freitas, J.P.X., Santos, V.S., and Oliveira, E.J. 2016. Inbreeding depression in cassava for productive traits. Euphytica 209:137145. doi:10.1007/s10681-016-1649-7.

Garbuglio, D.D., Miranda Filho, J.B., e Cella, M. 2009. Variabilidade genética em famílias S $_{1}$ de diferentes populações de milho. Acta Scientiarum Agronomy 31:209-213. doi:10.1590/S1807-86212009000200004.

Good, R.L., and Hallauer, A.R. 1977. Inbreeding depression in maize by selfing an full-sibbing. Crop Science 17:935-940. doi:10.2135/cropsci1977.0011183X001700060030x.

Hallauer, A.R. 1990. Methods used in developing maize inbreds. Maydica 35:1-16.

Hallauer, A.R., Carena, M.J., and Miranda Filho, J.B. 2010. Quantitative genetics in maize breeding. 664 p. Springer, New York, USA.

Ji, H.C., Cho, J.W., and Yamakawa, T. 2006. Diallel analysis of plant and ear heights in tropical maize (Zea mays L.) Journal of the Faculty of Agriculture - Kyushu University (Japan) 51:233-238.

Kuki, M.C., Scapim, C.A., Pinto, R.J.B., Figueiredo, A.S.T., Contreras-Soto, R.I., and Bertagna, F.A.B. 2017. Inbreeding depression and average genetic components in green corn genotypes. Ciência Rural 47(5):e20160024. doi:10.1590/0103-8478cr20160024.

Lima, M.W.P., Souza, E.A., e Ramalho, M.A.P. 2000. Procedimento para escolha de populações de milho promissoras para extração de linhagens. Bragantia 59:153-158. doi:10.1590/S0006-87052000000200005.

Marcondes, M.M., Faria, M.V., Mendes, M.C., Oliveira, B.R., Santos, J.F., Matchula, P.H., et al. 2015. Desempenho agronômico de linhagens $\mathrm{S}_{4}$ de milho em cruzamentos top crosses. Revista Brasileira de Milho e Sorgo 14:145-154. doi:10.18512/1980-6477/rbms.v14n1p145-154.

Miranda Filho, J.B., e Viégas, G.P. 1987. Milho híbrido. p. 277-326. In Paterniani, E., e Viégas, G.P. (eds.) Melhoramento e produção do milho. Fundação Cargill, Campinas, Brasil.

Nelson, P.T., and Goodman, M.M. 2008. Evaluation of elite exotic maize inbreds for use in temperate breeding. Crop Science 48:85-92. doi:10.2135/cropsci2007.05.0287.

Oliveira, A.S., Miranda Filho, J.B., and Reis, E.F. 2015. Variability and inbreeding in semiexotic maize populations. Genetics and Molecular Research 14:1184-1199. doi:10.4238/2015.February.6.21. 
Paterniani, M.E.A.G.Z., Luders, R.R., Duarte, A.P., Gallo, P.B., e Sawazaki, E. 2006. Desempenho de híbridos triplos de milho obtidos de top crosses em três locais do Estado de São Paulo. Bragantia 65:597-605. doi:10.1590/S0006-87052006000400010.

Scapim, C.A., Braccine, A.L., Pinto, R.J.B., Amaral Junior, A.T., Rodovalho, M.A., Silva, R.M., et al. 2006. Componentes genéticos de médias e depressão por endogamia em populações de milho pipoca. Ciência Rural 36:36-41. doi:10.1590/S0103-84782006000100006.

Senhorinho,H.J.C.,Pinto, R.J.B., Scapim,C.A., Milani, K.F., and Nihei,T.H. 2015.Combining abilities and inbreeding depression in commercial maize hybrids. Semina: Ciências Agrárias 36:4133-4150. doi:10.5433/1679-0359.2015v36n6Supl2p4133.

Vencovsky, R., e Barriga, P. 1992. Genética biométrica no fitomelhoramento. 496 p. Sociedade Brasileira de Genética, Ribeirão Preto, São Paulo, Brasil.

Viana, L.F., Souza, J.C., Machado, J.C., e Lima, J.L. 2009. Predição de médias de linhagens obtidas de híbridos simples de milho (Zea mays L.) Ciência e Agrotecnologia 33:1999-2004. doi:10.1590/S1413-70542009000700051. 